\title{
$\mathrm{Cu}-\mathrm{Ni}-\mathrm{Be}$ 合金の機械的，電気的特性とミクロ組織 ${ }^{\dagger}$
}

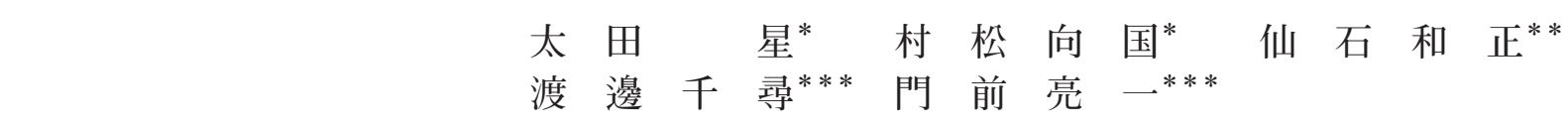

\section{Mechanical and Electrical Properties and Microstructure in Cu-Ni-Be Alloys}

by

\author{
Satoshi Ota ${ }^{*}$, Naokuni Muramatsu ${ }^{*}$, Kazumasa Sengoku ${ }^{* *}$, \\ Chihiro Watanabe ${ }^{* * *}$ and Ryoichi Monzen ${ }^{* * *}$
}

The yield strength and electrical conductivity of precipitation-hardenable $\mathrm{Cu}-2.05 \mathrm{mass} \% \mathrm{Ni}-0.35 \mathrm{mass} \% \mathrm{Be}$ and $\mathrm{Cu}$ $1.27 \mathrm{mass} \% \mathrm{Ni}-0.22 \mathrm{mass} \% \mathrm{Be}$ alloys aged at 360 to $560^{\circ} \mathrm{C}$ after cold rolling have been investigated. The former alloy exhibits a higher strength and a lower electrical conductivity in the under-aging and peak-aging stages, but a lower strength and a higher electrical conductivity in the over-aging stage than the latter alloy. Both alloys are hardened by plate-shaped coherent precipitates of $\gamma^{\prime \prime}$ phase, which is body-centered tetragonal with $a=b=0.24 \mathrm{~nm}$ and $c=0.28 \mathrm{~nm}$. In the peak-aging stage, the yield strength of both alloys is controlled by the precipitate shearing mechanism. Both alloys recrystallize in the over-aging stage at the coarse $\gamma$ precipitates which are residual even after solutionizing. A higher number density of the coarse $\gamma$ precipitates in the $\mathrm{Cu}-2.05 \% \mathrm{Ni}-0.35 \% \mathrm{Be}$ alloy gives rise to a larger volume fraction of recrystallization, resulting in a greater decrease in strength. The growth of incoherent precipitates in recrystallized grains is faster than that of coherent $\gamma^{\prime \prime}$ precipitates in unrecrystallized grains. This causes a higher electrical conductivity of the $\mathrm{Cu}-2.05 \% \mathrm{Ni}-0.35 \% \mathrm{Be}$ alloy in the over-aging stage.

Key words : Cu-Ni-Be alloy, Precipitation strengthening, Electrical conductivity, Recrystallization, $\gamma^{\prime \prime}$ precipitates

\section{1 緒言}

コネクタ, リードフレームなどの電子部品の小型化, 高密度化に伴い，それらの材料である銅合金にはますま す高強度, 高導電性が求められている。近年になって, 著しい自動車の電装化, パソコンの高出力化により高密 度電流が通電され, 材料自身の発熱が問題視されるよう になってきている。

析出硬化型合金である $\mathrm{Cu}-\mathrm{Be}$ 系合金は銅合金の中で最 も優れた時効硬化性を示し，また優れた耐食性，高導電 性を有するため, パソコンや携帯電話などのコネクタや 機械部品などに広く使用されている。この優れた硬化性 は溶体化処理後の時効により達成され，その析出過程は 数多くの研究によりほぼ明らかになっている.1) - 3)一方, 析出硬化型のベリリウム銅合金の中でも, Cu-Be 系合金 に比べ Be 含有量が少ない $\mathrm{Cu}-\mathrm{Ni}-\mathrm{Be}$ 系合金は強度は劣る ものの, 導電性に秀でており, 古くから研究開発が進め られてきた。しかし, 機械的特性や電気的特性とミクロ 組織との関係についての報告例はあまり見当らない. しかも, 析出強化相の同定はこれまでよく研究されている $\mathrm{Cu}$-Be 合金中の析出相 ${ }^{1),}$ 2)の電子回折図形との類似性か ら行われてはいるが，析出相の構造が直接決定されてい るわけではない.

本研究では，Cu-2.05mass\%Ni-0.35mass\%Be 実用合金お
よび導電性の向上を目的として $\mathrm{Ni}$ と $\mathrm{Be}$ の含有量を減ら した Cu-1.27mass\%Ni-0.22mass\%Be 合金を圧延後 $360^{\circ} \mathrm{C}$ から $560^{\circ} \mathrm{C}$ までの温度で時効し, 機械的, 電気的特性を 調べるとともに，透過型電子顕微鏡 $(\mathrm{TEM})$, 高分解能 (HR) TEM によりミクロ組織を調査した.

\section{2 実 験 方 法}

$\mathrm{Ni}$ と $\mathrm{Be}$ の原子分率 $(\mathrm{Ni} / \mathrm{Be})$ が近似的に $1: 1$ である, 11 合金 (C17510) と呼ばれる Cu-2.05mass\%Ni-0.35mass \%Be 実用合金と Cu-1.27mass\%Ni-0.22mass\%Be 合金の鋳 塊を真空誘導溶解炉で溶製した。以後，両合金をそれぞ れ高濃度材，低濃度材と呼ぶ。これらの合金を $900^{\circ} \mathrm{C} て ゙$ 均質化処理後, 冷間圧延, 軟化焼鈍を行った。つい゙ソ

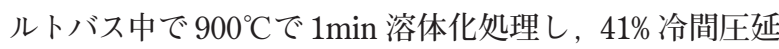
を加えた後, $360 \sim 560^{\circ} \mathrm{C}$ 真空中で $6 \mathrm{~h}$ 時効を行い供試材 とした.

走査型電子顕微鏡 $(\mathrm{SEM})$ を使った組織観察と，加速 電圧 $300 \mathrm{kV}$ で日立製 H-9000NAR 型 TEM を用いた観察 を行った。またTEM に内蔵されているエネルギー分散 型分析装置 (EDX) を用いて析出物の濃度分析を行った。 比抵抗は $20^{\circ} \mathrm{C} て ゙ 4$ 端子法にて測定した。引張試験は平行 部が $50 \mathrm{~mm} \times{ }^{w} 12.5 \mathrm{~mm} \times{ }^{t} 0.24 \mathrm{~mm}$ の板状肩付き試験片 を作製後，インストロン型万能試験機によりひずみ速度 $3 \times 10^{-4} \mathrm{~s}^{-1}$ の条件で室温大気中にて実施した.

$\dagger$ 原稿受理 平成 18 年 10 月 31 日 Received Oct. 31, 2006 @ 2007 The Society of Materials Science, Japan

* 日本ガイシ(株) †475-0836 半田市前潟町, NGK Insulators ltd., Maegata-cho, Handa, 475-0836

** 金沢大学大学院 干920-1192 金沢市角間町, Graduate Student, Kanazawa Univ., Kakuma-machi, Kanazawa, 920-1192

*** 正会員 金沢大学大学院自然科学研究科 =920-1192 金沢市角間町, Graduate School of Natural Sci., Kanazawa Univ., Kakuma-machi, Kanazawa, 920-1192 


\section{$3 \cdot 1$ 析出相の同定}

\section{3 実 験 結 果}

$\mathrm{Cu}-\mathrm{Be}$ 合金の時效により G.P.ゾーン $\rightarrow \gamma^{\prime \prime}$ 相 $\rightarrow \gamma^{\prime}$ 相 $\rightarrow$ $\gamma$ 相という順に相変態が起こることが一般に認めらてお り, 各相の構造も X線回折, TEM, HRTEM によって決 定されている.1) 3) しかし，Cu-Ni-Be 合金においては時 効に伴う析出順が調べられていないのみならず, 各相の 構造も十分には明らかにされていない．

Fig. 1 (a)に, ピーク強度を示した $400^{\circ} \mathrm{C} て ゙ ~ 6 h$ 時効後の 高濃度材に打いて析出物の HRTEM 像とこれに対応した 電子回折図形 (SADP) を示す. 電子線入射方向は $\mathrm{Cu}$ 母 相の $[100]_{\alpha}$ 方向に平行である. SADPにおいて，<002>o 方向に沿ったストリーク中に強度極大点が $2 / 3\{002\}_{\alpha}$ 逆 格子点付近に観察される。このような強度極大は, $\mathrm{Cu}-\mathrm{Be}$ 合金中に $\gamma^{\prime \prime}$ 相が存在するときにも認められており, 1) 3) 従って $\{100\}_{\alpha}$ 面に平行な板状析出物は $\gamma^{\prime \prime}$ 相と推定され る。 Fig. 1 (a)の格子像には， Ni または $\mathrm{Cu}$ 原子層を挟 んで $\{001\}_{\alpha}$ に平行な 2 層の Be 原子層のコントラストが 見られ，Cu-Be 合金単結晶に打ける HRTEM 観察結果 ${ }^{3)}$ に従えば, Be 層の間隔は $\gamma^{\prime \prime}$ 析出物の $(001)_{\gamma^{\prime \prime}}$ 面の間隔に 対応する。.また, $\{110\}_{\alpha}$ 面に垂直な電子線を使って得ら れる析出物の格子像から (100) $\gamma^{\prime \prime}$ と(010) $\gamma^{\prime \prime}$ 面の間隔を求
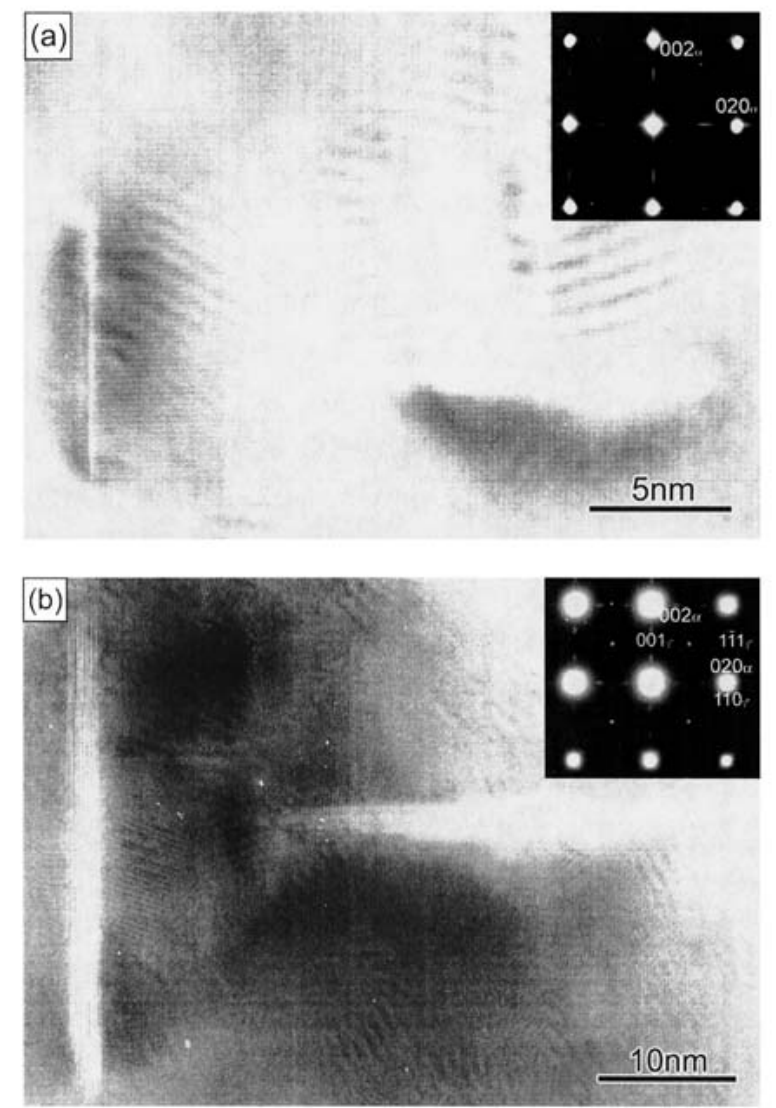

Fig. 1 HRTEM images of plate-shaped $\gamma^{\prime \prime}$ precipitates in (a) a Cu-2.05mass\%Ni-0.35mass\%Be alloy, peakaged at $400^{\circ} \mathrm{C}$ for $6 \mathrm{~h}$ and (b) a $\mathrm{Cu}-1.27 \mathrm{mass} \% \mathrm{Ni}-$ $0.22 \mathrm{mass} \% \mathrm{Be}$ alloy, over-aged at $560^{\circ} \mathrm{C}$ for $6 \mathrm{~h}$. A $[100]_{\alpha}$ selected-area diffraction pattern (SADP) corresponding to (a) or (b) is inserted.
めることができる。解析の結果, $\gamma^{\prime \prime}$ 析出物の構造は格子 定数 $a=b=0.24 \mathrm{~nm}, c=0.28 \mathrm{~nm}$ の体心正方晶であるこ とが判明した。これらの值は $\mathrm{Cu}-\mathrm{Be}$ 系合金中の $\mathrm{CuBe}$ 金 属間化合物である $\gamma^{\prime \prime}$ 析出相において報告されている, 1), 3) $a=b=0.25 \mathrm{~nm}, c=0.29 \mathrm{~nm}$ よりわずかに小さいが，よく 似ている。 その上 EDX 分析の結果, 板状 $\gamma^{\prime \prime}$ 析出物には $\mathrm{Ni}$ が検出されたことから, この $\gamma^{\prime \prime}$ 析出物は NiBe もし くは $(\mathrm{Cu}, \mathrm{Ni}) \mathrm{Be}$ 金属間化合物と判断される. $360^{\circ} \mathrm{C}$ で時 効したときも，そのサイズは小さいが，2 層の Be 原子層 よりなる板状 $\gamma^{\prime \prime}$ 析出相が形成された。 Fig. 1 (b)に, 本 研究で最も高い温度 $560^{\circ} \mathrm{C} て ゙ 6 \mathrm{~h}$ 時効後の低濃度材に打 いて析出物の HRTEM 像と $[100]_{\alpha}$ SADP を示す. SADP には $2 / 3\{002\}_{\alpha}$ 逆格子点付近の強度極大が観察されるた め, $\{100\}_{\alpha}$ に平行で平均で約 8 層の Be 積層数をもつ板 状析出物は未だ $\gamma^{\prime \prime}$ 相と判断できる。この強度極大の他 $に 1 / 3\{002\}_{\alpha}$ 逆格子点付近の強度極大と $1 / 2\{022\}_{\alpha}$ 逆格 子点付近に斑点が確認される。前者は 2 重回折による禁 制斑点であり，後者は $(100)_{\alpha}$ に平行な板状 $\gamma^{\prime \prime}$ 析出物の 100 と 010 斑点である。これらの析出物の斑点と格子像の 解析から, Fig. 1 (a)の 2 層析出物の場合と同様の $a=b=$ $0.24 \mathrm{~nm}, c=0.28 \mathrm{~nm}$ が得られた。最近, Monzen $ら^{33}$ は $\mathrm{Cu}-0.9$ mass\%Be 合金単結晶に打ける析出過程を調查し， $\mathrm{Be}$ 積層数が 8 層にもなると $\gamma_{\mathrm{I}}^{\prime}$ 相と呼ばれる， $\gamma^{\prime}$ 相への 変態前に形成され， $\gamma^{\prime \prime}$ 相とは異なった構造の相に変化す ることを報告して打り，このことだけでも Cu-Ni-Be 合金 中の析出過程が $\mathrm{Cu}-\mathrm{Be}$ 合金中のそれと必ずしも同一では ないことが分かる.また, Fig. 1 (b)中の $(001)_{\alpha}$ 面に平 行な板状 $\gamma^{\prime \prime}$ 析出物の斑点と $\mathrm{Cu}$ 母相の斑点から, 次の Bainの方位関係が成立していることが見出せる.

$$
[100]_{\alpha} / /[110]_{\gamma^{\prime \prime}} ;(001)_{\alpha} / /(001)_{\gamma^{\prime \prime}}
$$

以上のように, すべての時効温度において高濃度材, 低濃度材ともに $\gamma^{\prime \prime}$ 析出相が観察され，次節に示される 本研究における析出強化は $\gamma^{\prime \prime}$ 析出相によりもたらされ ることが分かる.

一方, 鋳造後, 結晶粒内・粒界に粗大な粒子が観察さ れ, 鋳塊の均質化処理後もその析出物の数密度, 大きさ, 形状は変化したが，矢の存在が確認された。さうに軟化 焼鈍，溶体化処理後にも，Fig. 2 に示すように粗大な粒 子が観察された. $\mathrm{Cu}-\mathrm{NiBe}$ 擬 2 元状態図 ${ }^{6}$ に従えば, こ れらの析出物は鋳造後の安定 $\gamma$-NiBe 析出物が残存した ものと判断できる. Fig. 2 で Ni および Be の添加量の多 い高濃度材で粗大析出物の数密度が高い. Fig. 3 に $1 \mu \mathrm{m}$ 程度の粗大析出物の TEM 像と只の析出物の $[001]_{\gamma}$ SADP を示す. 多数の粗大析出物の SADP の解析より粗大析出 物の格子定数 $a=0.26 \mathrm{~nm}$, 結晶構造は $\mathrm{B} 2$ 型であること, また EDX 分析より $\mathrm{Ni}$ のみが検出されたことから，溶体 化処理後に観察された粗大析出物は安定 $\gamma$ - NiBe 相であ ることが判明した。

\section{$3 \cdot 20.2 \%$ 耐力と導電率の時効温度変化}

Fig. 4 に時効温度に対する $0.2 \%$ 耐力の変化を示す. 高 濃度材, 低濃度材いずれも $400^{\circ} \mathrm{C}$ 近辺でピーク強度を迎 え, 光の強度レベルは $\mathrm{Ni}, \mathrm{Be}$ 添加量の多い高濃度材の方 

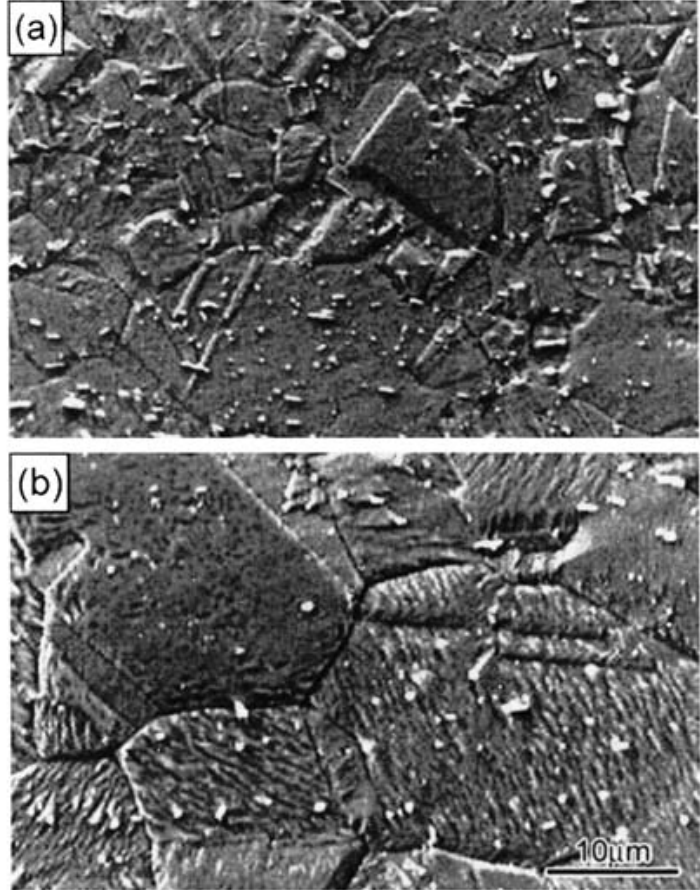

Fig. 2 SEM images of (a) a Cu- $2.05 \% \mathrm{Ni}-0.35 \%$ Be alloy and (b) a $\mathrm{Cu}-1.27 \% \mathrm{Ni}-0.22 \% \mathrm{Be}$ alloy after solution treatment at $900^{\circ} \mathrm{C}$ for $1 \mathrm{~min}$.

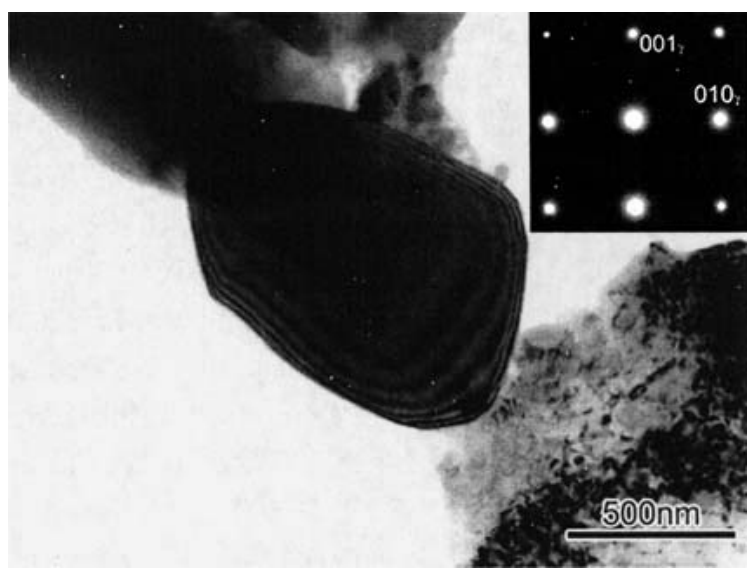

Fig. 3 TEM image of a coarse $\gamma$-NiBe precipitate and $[100]_{\gamma}$ SADP of the $\gamma$ precipitate in a $\mathrm{Cu}-2.05 \% \mathrm{Ni}-$ $0.35 \%$ Be alloy aged at $400^{\circ} \mathrm{C}$ for $6 \mathrm{~h}$ after solution treatment at $900^{\circ} \mathrm{C}$ for $1 \mathrm{~min}$ and subsequent cold rolling.

が大きい。一方, 約 $500^{\circ} \mathrm{C}$ 以上の過時効領域では低濃度 材の方で強度が大きくなり，強度の逆転が起こっている.

Fig. 5 に見られるように, 約 $500^{\circ} \mathrm{C}$ 以上の時効後, 粗 大 $\gamma$ 析出物の近傍でしばしば再結晶粒が形成された。再 結晶粒の割合を SEM 写真の画像処理にて面積率として 求めた結果， $500^{\circ} \mathrm{C} ， 560^{\circ} \mathrm{C}$ 時効において高濃度材で $26 \%$, $91 \%$ ，低濃度材で $1 \% ， 15 \%$ であった。また，SADP と菊 池線の解析により粗大 $\gamma$ 析出物のごく近傍とそれより離 れた領域との間には約 $3^{\circ}$ の方位差が認められた。つま り，粗大 $\gamma$ 相周辺に圧延時の加工ひずみが集中していた ことが分かる。このように，粗大粒子周辺に加工ひずみ

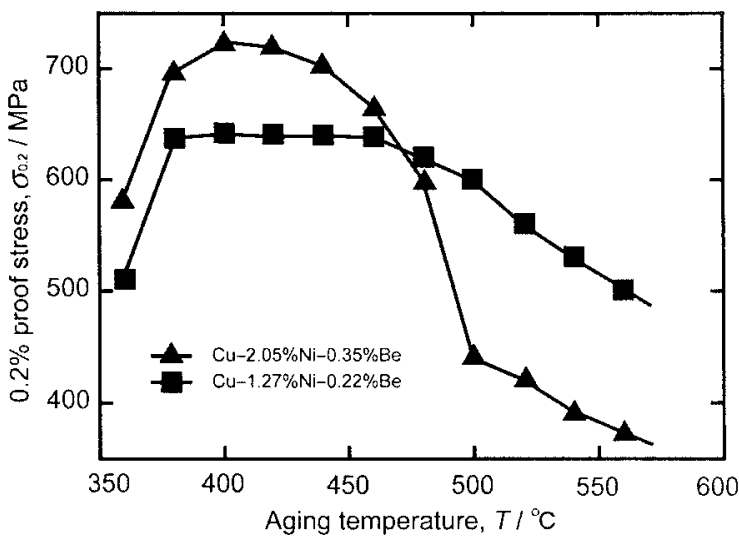

Fig. 4 Dependence of $0.2 \%$ proof stress on aging temperature for $\mathrm{Cu}-2.05 \% \mathrm{Ni}-0.35 \% \mathrm{Be}$ and $\mathrm{Cu}$ $1.27 \% \mathrm{Ni}-0.22 \% \mathrm{Be}$ alloys aged for $6 \mathrm{~h}$.

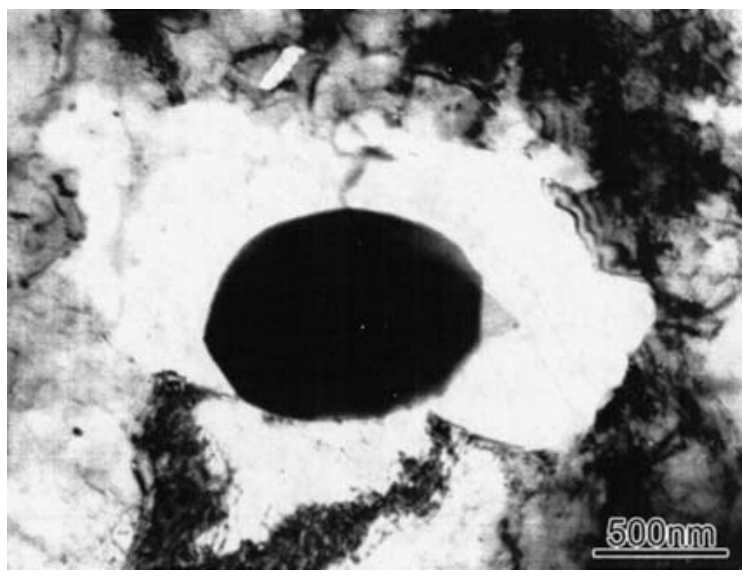

Fig. 5 Nucleation of recrystallization at a coarse $\gamma$ precipitate in a $\mathrm{Cu}-2.05 \% \mathrm{Ni}-0.35 \% \mathrm{Be}$ alloy aged at $500^{\circ} \mathrm{C}$ for $6 \mathrm{~h}$.

の蓄積が生じ, 粗大粒子周りに再結晶核が形成されるこ とは，これまでしばしば報告されている.7)従って，再結 晶核の生成サイトとして作用する粗大 $\gamma$ 析出相の数密度 の高い高濃度材の方が再結晶粒の割合が大きくなり，結 果として高温側では強度が大きく低下したと言える。

Table 1 に $400^{\circ} \mathrm{C}$ で $6 \mathrm{~h}$ 時効後の高濃度材と低濃度材中 の $\gamma^{\prime \prime}$ 相の析出による $0.2 \%$ 而力の増加分, 析出物のサイ ズと体積分率を示す。ここで $r$ は板状析出物の半径, $h$ は厚さを表す。体積分率 $f$ は析出物を全て $\mathrm{NiBe}$ のみと 仮定し, 時効処理前後の導電率と $\mathrm{Ni}, \mathrm{Be}$ の比抵抗への 寄与 ${ }^{8)}$ より求めた。両試料間で析出硬化量にほとんど差 が認められない.

Table 1 Strength increment $\Delta \sigma$ due to plate-shaped $\gamma^{\prime \prime}$ precipitates, and radius $r$, thickness $h$ and volume fraction $f$ of $\gamma^{\prime \prime}$ precipitates in $\mathrm{Cu}-2.05 \% \mathrm{Ni}-0.35 \% \mathrm{Be}$ and $\mathrm{Cu}-1.27 \% \mathrm{Ni}-0.22 \% \mathrm{Be}$ alloys, peak-aged at $400^{\circ} \mathrm{C}$ for $6 \mathrm{~h}$.

\begin{tabular}{c|c|c|c|c}
\hline Alloy & $\Delta \sigma /[\mathrm{MPa}]$ & $r /[\mathrm{nm}]$ & $h /[\mathrm{nm}]$ & $f$ \\
\hline Cu-2.05Ni-0.35Be & 265 & 6 & 0.6 & 0.88 \\
\hline Cu-1.27Ni-0.22Be & 258 & 6 & 0.6 & 0.83 \\
\hline
\end{tabular}


Fig. 6 に時効温度に対する導電率の变化を示す. 高濃 度材, 低濃度材いずれも時効温度の上昇とともに導電率 は増加し，容易に予想されるように，低温側において低 濃度材ではより高い導電率を示している。しかし, 約 $500^{\circ} \mathrm{C}$ で両合金の導電率の差は消滅し，さらに高温側で は高濃度材の方が導電率が高くなり逆転が起こっている.

強度がピークとなった $400^{\circ} \mathrm{C}$ の時効では, 高濃度材と 低濃度材の導電率の差は，主として溶体化処理時の固溶 量の差を反映していると言える。一方， $500^{\circ} \mathrm{C}$ 以上での 導電率の逆転は，再結晶の割合の差，すなわち転位密度 等の差の現れであると考えられる。これを調べるため， 純銅を $41 \%$ 冷間圧延して導電率を測定した。転位密度等 の増加による導電率の低下は約 $3 \% \mathrm{IACS}$ であった. $560^{\circ} \mathrm{C}$ で時効を行ったときを考えると，再結晶率の違いにより 高濃度材の導電率が約 $2 \% \mathrm{IACS}$ 高くなるはずである。し かし，この程度高くなっても Fig. 6 の導電率の逆転現象 は説明できない。このことについては別項において検討 を加える。

Fig. 4 と Fig. 6 の結果は，適切な熱処理を行えば，低 濃度材は実用合金の組成である高濃度材と同等以上の強 度・導電率のバランスを有していることを示しており， 高密度電流が通電される電子部品の小型化, 高密度化へ の貢献が期待される.

$$
4 \text { 考察 }
$$

\section{$4 \cdot 1$ 降伏機構}

$\mathrm{Al}$ 合金に扎いては，析出粒子が比較的小さいときは転 位のせん断機構により，硬さのピークを過ぎた時点で析 出粒子が大きいときはオロワン機構により降伏が生じる と報告されている.9), 10) これは巨視的には変形初期の加工 硬化率の違いとなって現れ，せん断機構によるとき加工 硬化は小さく，オロワン機構では粒子周りのオロワンルー プによる逆応力のため加工硬化は大きいことが知られて いる.11) 13)そこで本研究に扎いてピーク時効段階でどち らの機構によって降伏強さが支配されるのかを調べるこ ととした。このため, $900^{\circ} \mathrm{C} て ゙ 1 \mathrm{~h}$ の溶体化处理に続いて の $41 \%$ 圧延後，それぞれ亜時効，ピーク時効，過時効に

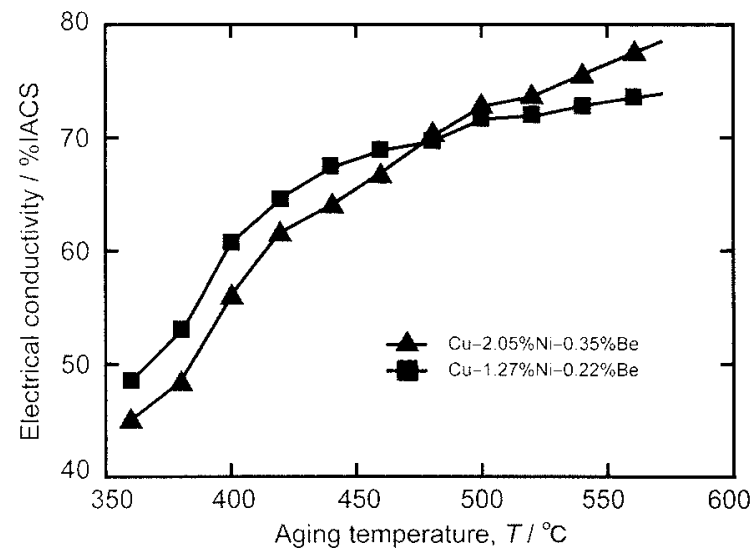

Fig. 6 Dependence of electrical conductivity on aging temperature for $\mathrm{Cu}-2.05 \% \mathrm{Ni}-0.35 \% \mathrm{Be}$ and $\mathrm{Cu}$ $1.27 \% \mathrm{Ni}-0.22 \% \mathrm{Be}$ alloys aged for $6 \mathrm{~h}$.
相当する $400^{\circ} \mathrm{C}$ で $2 \mathrm{~h}, 6 \mathrm{~h}, 500^{\circ} \mathrm{C}$ で $8 \mathrm{~h}$ 時効した高濃度材

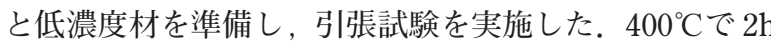
と $500^{\circ} \mathrm{C}$ で $8 \mathrm{~h}$ の時効条件は硬さがほぼ同じになるように 選んだ。 $900^{\circ} \mathrm{C}, 1 \mathrm{~h}$ で溶体化处理を行ったのは，時効時 にできるだけ多くの $\gamma^{\prime \prime}$ 相を析出させ，もし時効条件に よって加工硬化率に違いが現れるならば，その違いを明 瞭にするためである. $500^{\circ} \mathrm{C} て ゙ ~ 8 \mathrm{~h}$ 時効後においても，溶 体化処理の時間が長いため粗大 $\gamma$ 析出物の数密度が減少 し，再結晶はほとんど生じなかった。Fig. 7 に高濃度材 に約 $2 \%$ の引張ひずみを与えたときの応力ーひずみ曲線 を示す．過時効材は亜時効材とピーク時効材と比べ大き な加工硬化を示している。析出粒子周りのオロワンルー プはパイプ拡散により比較的低温の焼鈍で消滅すること

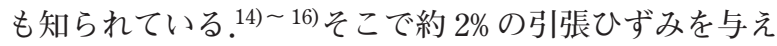
た後 $200^{\circ} \mathrm{C} て ゙ 30 \mathrm{~min}$ で焼鈍し，再び引張試験を行った結 果を Fig. 7 にあわせて示す。過時効段階において加工硬 化後の焼鈍による軟化が見られ，ピーク時効段階では焼 鈍による軟化は観察されない. $400^{\circ} \mathrm{C} て ゙ 6 \mathrm{~h}$ 時効した低濃 度材に扎いても， $2 \%$ の引張ひずみを与え $200^{\circ} \mathrm{C} て ゙ ~ 30 \mathrm{~min}$ の焼鈍後軟化は認められなかった。以上の結果より，本 研究に打けるピーク時効材の降伏はせん断機構により生 ずると結論される。

せん断機構によって降伏が生ずるとき, 析出硬化量 $\Delta \sigma$ は球状析出物の体積分率 $f$, 平均半径 $r$ の関数として次 式によって表される.17)

$$
\Delta \sigma \propto(f \cdot r)^{1 / 2}
$$

この式から, Table 1 に見られるように, 両合金で $\gamma^{\prime \prime}$ 相の 析出による強度増加への寄与がほぼ等しいのは析出物の 体積分率，サイズがほとんど等しいためであると言える.

\section{$4 \cdot 2$ 高温における導電率の逆転}

Fig. 8 は高濃度材の $560^{\circ} \mathrm{C}$ で $6 \mathrm{~h}$ 時効における再結晶 領域の析出物の TEM 像と [111] $\gamma^{\prime}$ SADP である. Fig. 1 (b)に示すように，未再結晶領域の析出物の形状は板状て あるが，再結晶領域の析出物は球状となっている。析出 物の SADP の解析の結果, 球状析出物は $a=0.24 \mathrm{~nm}$, $b=c=0.26 \mathrm{~nm}$ をもつ体心正方晶の $\gamma^{\prime}$ 相であることがわ かった。これは，これまでに報告されている $\mathrm{Cu}-\mathrm{Be}$ 合金 中の各析出相の格子定数から判断した.2), 3) 板状 $\gamma^{\prime \prime}$ 析出

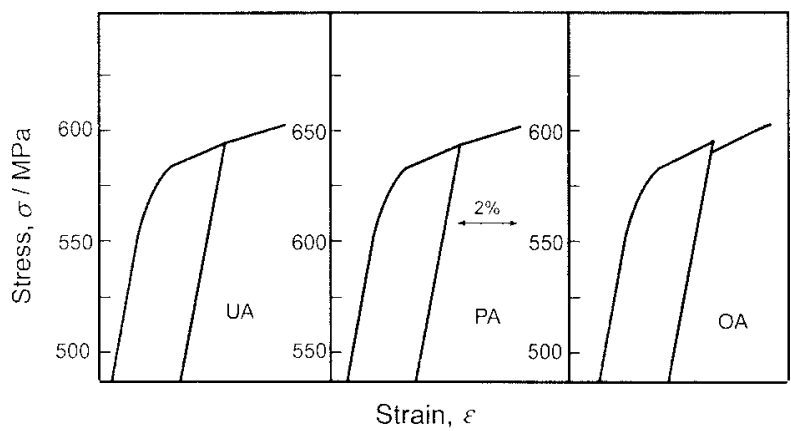

Fig. 7 Stress-strain curves before and after annealing at $200^{\circ} \mathrm{C}$ for $30 \mathrm{~min}$ for $\mathrm{Cu}-2.05 \% \mathrm{Ni}-0.35 \% \mathrm{Be}$ specimens aged at $400^{\circ} \mathrm{C}$ for $2 \mathrm{~h}(\mathrm{UA})$, at $400^{\circ} \mathrm{C}$ for $6 \mathrm{~h}(\mathrm{PA})$, and at $500^{\circ} \mathrm{C}$ for $8 \mathrm{~h}(\mathrm{OA})$ 


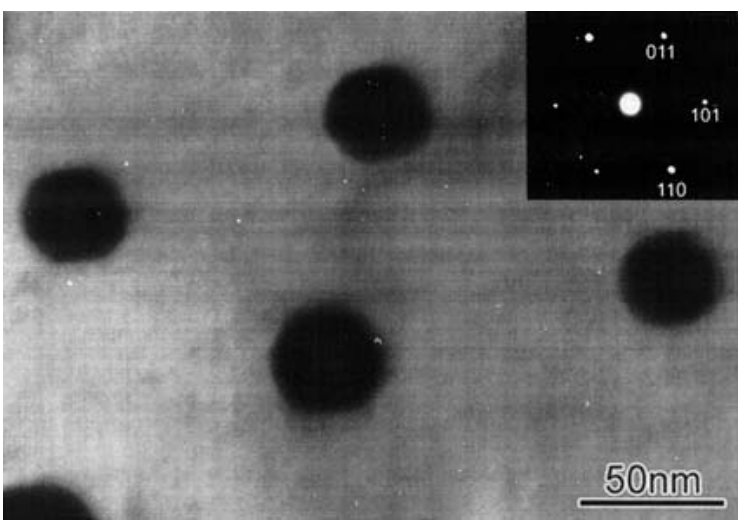

Fig. 8 TEM image of spherical $\gamma^{\prime}$ precipitates and [111] $_{\gamma^{\prime}}$ SADP of the $\gamma^{\prime}$ precipitates in a recrystallized grain in a $\mathrm{Cu}-2.05 \% \mathrm{Ni}-0.35 \% \mathrm{Be}$ alloy, over-aged at $560^{\circ} \mathrm{C}$ for $6 \mathrm{~h}$.

物は再結晶後母相との方位関係を持たず非整合となった ため, 界面エネルギーの異方性がなくなるとともに増加 し, 結果として球状への変化と同時により安定な $\gamma^{\prime}$ 相へ と急激に変態したと考えることができる。

Fig. 9 に高濃度材を $560^{\circ} \mathrm{C}$ で時効したときの球状と板 状析出物の平均体積を $5 \mathrm{~h}$ からの時効時間 $t$ の関数とし て示す。低濃度材に打いてもまったく同じ曲線が得られ た. $5 \mathrm{~h}$ の時效後再結晶が生じた直後より球状粒子の体積 は短時間で急激に増加し, その後その変化は小さくなり 約 $12 \mathrm{~h}$ 後 $t$ とほぼ直線関係をもつ。すなわち, この段階 では平均球状粒子の半径 $r$ と $t$ の間には $r^{3}-r_{0}^{3} \propto t$ が成 立し, 粗大化成長の Lifshitz-Slyozov-Wagner 理論 ${ }^{18), 19}$ と一致する。ここで $r_{0}$ は粗大化成長開始時の粒子の半径 である。従って, 粗大化成長開始前には再結晶粒中の溶 質濃度は過飽和状態にあると言える。

$\mathrm{Cu}-\mathrm{Ni}-\mathrm{Be}$ 合金の中間相に対する固溶限曲線はこれまで 報告されていないので， $\mathrm{Cu}-\mathrm{Be}$ 合金の中間相についての 固溶限曲線 ${ }^{20}$ に従うと, $\gamma^{\prime \prime}$ 相の固溶限は $\gamma^{\prime}$ 相のそれよ り大きい。従って, 再結晶により $\gamma^{\prime \prime}$ 相から $\gamma^{\prime}$ 相に変化 すると母相中の $\mathrm{Ni}$ と $\mathrm{Be}$ の過飽和度が大きくなり，結果

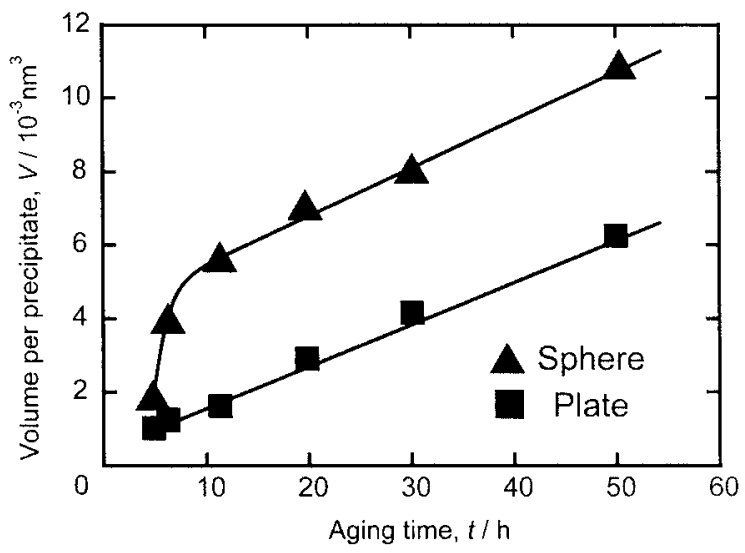

Fig. 9 Variation in the volume of spherical and plateshaped precipitates in a $\mathrm{Cu}-2.05 \% \mathrm{Ni}-0.35 \% \mathrm{Be}$ alloy during aging at $560^{\circ} \mathrm{C}$.
として析出物に向かって拡散する溶質原子量が多くなり， 球状析出物の成長速度が大きくなったと理解される。こ のため, 高温で再結晶率の大きい高濃度材では低濃度材 に比べ導電率が大きく増加し，導電率の逆転が起きたと 言える.

\section{5 結 言}

圧延後 $360^{\circ} \mathrm{C}$ から $560^{\circ} \mathrm{C}$ までの温度で時効された $\mathrm{Cu}$ $2.05 \% \mathrm{Ni}-0.35 \% \mathrm{Be}$ 合金（高濃度材）と Cu-1.27\% Ni$0.22 \% \mathrm{Be}$ 合金(低濃度材)の降伏強さと導電率を調査し, 組織学的に検討を加えた。得られた結言は以下のように 要約される。

（1） 高濃度材は带時効，ピーク時効段階では低濃度材 に比べ強度は高いが，過時効段階では逆に強度は低い． この著しい過時効軟化は溶体化处理後残存する粗大な $\gamma$ 析出物が再結晶の核生成サイトとして作用し, 学の析出 物の数密度が高濃度材の方が高いことに起因する。

（2）時効硬化は板状の整合 $\gamma^{\prime \prime}$ 析出物により起こる. $\gamma^{\prime \prime}$ 相は格子定数 $a=b=0.24 \mathrm{~nm}, c=0.28 \mathrm{~nm}$ をもつ体心 正方晶であり, $\mathrm{Cu}$ 母相との間に Bain の方位関係を持つ.

（3）ピーク時効段階における両合金の降伏強さは析出 物のせん断機構によって支配される。

（4）高濃度材は带時効，ピーク時効段階では低濃度材 に比べ導電率が低く，過時効段階では高くなり逆転が起 こる. 導電率の逆転は主として再結晶粒中の非整合析出 物の成長速度が未再結晶粒中の整合 $\gamma^{\prime \prime}$ 析出物のそれよ り大きいことによる。

透過型電子顕微鏡の使用にあたりご協力いただいた北 陸先端科学技術大学院大学ナノマテリアルテクノロジー センターの東嶺孝一技術官に感謝する。

\section{参 考 文 献}

1) K. Shimizu, Y. Mikami, H. Mitani and K. Otuka, "Electron microscopy study of the precipitation processes in $\mathrm{Cu}$ $2 w t \% B e$ alloy", Journal of the Japan Institute of Metals, Vol.34, No.11, pp.1108-1115 (1970).

2 ) R. J. Rioja and D. E. Laughlin, "The sequence of precipitation in Cu-2wt\%Be alloys”, Acta Metallurgica, Vol.28, No.9, pp.1301-1313 (1980).

3 ) R. Monzen, T. Seo, T. Sakai and C. Watanabe, "Precipitation processes in a $\mathrm{Cu}-0.9$ mass $\%$ Be single crystal”, Materials Transactions, Vol.47, No.12, pp.2925-2934 (2006).

4 ) A. Guha, "Development of a high strength high conductivity Cu-Ni-Be alloy”, Proceedings of the annual meeting of Metallurgical Society of AIME, pp.133-145 (1984).

5 ) D. H. Plantz, R. A. Dodd and G. L. Kulcinski, "Mechanical property changes in Ion-irradiated metals : Part II. Highstrength Cu-Ni-Be alloy”, Metallurgical Transactions A, Vol.20, No.12, pp.2689-2693 (1989).

6 ) S. Spaic and B. Markoli, "Microstructural characterization of alloys of the quasibinary Cu-NiBe system”, Zeitschrift für Metallkunde, Vol.94, No.8, pp.876-879 (2003).

7 ) F. J. Humphreys and M. Hatherly, "Recrystallization and 
related annealing phenomena”, pp.235-279 (1995) Pergamon Press.

8 ) F. Pawlek and K. Reichel, "The influence of impurities on the electrical conductivity of copper”, Zeitschrift für Metallkunde, Vol.47, No.6, pp.347-356 (1956).

9 ) K. Osamura, S. Ochiai and T. Uehara, "Precipitation behavior and change of yield strength during artificial aging in Al$\mathrm{Zn}-\mathrm{Mg}-\mathrm{Cu}$ alloys”, The Japan Institute of Light Metals, Vol.34, No.9, pp.517-524 (1984).

10) E. A. Marquis, D. N. Seidman and D. C. Dunand, "Effect of $\mathrm{Mg}$ addition on the creep and yield behavior of an Al-Sc alloy”, Acta Materialia, Vol.51, No.16, pp.4751-4760 (2003).

11) K. Tanaka and T. Mori, "Hardening of crystals by nondeforming particles and fibers", Acta Metallurgica, Vol.18. No.8, pp.931-941 (1970).

12) L. M. Brown and W. M. Stobbs, "The work-hardening of copper-silica I. A model based on internal stresses, with no plastic relaxation”, Philosophical Magazine, Vol.23, No.185, pp.1185-1199 (1971)

13) T. Mori and K. Tanaka, "Average stress in matrix and average elastic energy of materials with misfitting inclusions", Acta Metallurgica, Vol.21, No.5, pp.571-574 (1973).
14) T. Mori and H. Tokushige, "Effect of particle size on low temperature softening of work hardened $\mathrm{Cu}-\mathrm{SiO}_{2}$ crystals", Acta Metallurgica, Vol.25, No.6, pp.635-641 (1977).

15) T. Mori and T. Osawa, "Softening of work-hardened Al-Si crystals and low-temperature creep”, Philosophical Magazine, Vol.40, No.4, pp.445-457 (1979).

16) R. Monzen, Y. Kawaguchi and T. Mori, "Back stress hardening and static and dynamic softening in a $\mathrm{Cu}$ alloy with $\alpha$-Fe particles”, Acta Metallurgica, Vol.30, No.5, pp.965-972 (1982).

17) V. Gerold and H. Haberkorn, "On the critical resolved shear stress of solid solutions containing coherent precipitates", Physica Status Solidi, Vol.16, No.2, pp.675-684 (1966).

18) I. M. Lifshitz and V. V. Slyozov, "The kinetics of precipitation from supersaturated solid solutions", Journal of Physics and Chemistry of Solids, Vol.19, No.1-2, pp.35-50 (1961).

19) C. Wagner, "Theory of precipitate change by redissolution", Zeitschrift für Elektrochemie und Angewandte Physikalische Chemie, Vol.65, No.7-8, pp.581-591 (1961).

20) D. J. Chakrarti, D. E. Laughlin and L. E. Tanner, "The Be-Cu system”, Bulletin of Alloy Phase Diagrams, Vol.8, No.3, pp.269-282 (1981). 